ISSN: 1978-7057

\title{
PENGARUH GAJI, PENGEMBANGAN KARIR DAN LINGKUNGAN KERJA FISIK TERHADAP PRODUKTIVITAS KERJA KARYAWAN PT. BANK TABUNGAN NEGARA (Persero) Tbk KC MEDAN I
}

\author{
Pebriyati Purba \\ Alumni Jurusan Manajemen Fakultas Ekonomi Jurusan Manajemen \\ Dina Sarah Syahreza \\ Dosen Jurusan Manajemen Fakultas Ekonomi Jurusan Manajemen
}

\begin{abstract}
Abstrak
Banyak sekali factor-faktor yang mempengaruhi produktivitas kerja karyawan.Beberapa faktor yang mempengaruhi produktivitas karyawan adalah gaji, pengembangan karir dan lingkungan kerja fisik. Penelitian ini meneliti tentang pengaruh gaji , pengembangan karir dan lingkungan kerja terhadap produktivitas karyawan yang bekerja di Bank Tabungan Negara Cabang Medan. Karyawan yang di teliti adalah karyawan tetap yang bekerja pada Bank Tersebut,Berdasarkan hasil dari analisis data dengan regresi didapatkan bersamaan $Y=9604+0.036+0.396 \times 1 \times 2+x 3+e 0.315$ Hal ini mengungkapkan bahwa ada pengaruh gaji, pengembangan karir dan Lingkungan Kerja Fisik secara bersama - sama kepada produktivitas karyawan.
\end{abstract}

Kata kunci: Gaji, Pengembangan Karir, Lingkungan Kerja Fisik

\section{PENDAHULUAN}

Dalam dunia kerja usaha di era globalisasi ini, karyawan merupakan aset yang paling penting dalam proses berjalannya suatu badan usaha, karyawan memiliki fungsi yang paling utama dan pengaruh yang paling besar untuk kemajuan suatu badan usaha ataupun perusahaan. Untuk melihat suatu perkembangan karyawan berdasarkan kemajuan teknologi masa kini dapat dilakukan berdasarkan produktivitas kerja karyawan.Karena produktivitas sangat berpengaruh terhadap kemajuan ataupun perkembangan sebuah badan usaha dan juga dalam penentuan kemerosotan sebuah badan usaha.Semakin baik produktivitas yang dimiliki karyawan di dalam sebuah badan usaha maka dapat dikatakan badan usaha tersebut juga berkembang dengan baik.

Dalam mengelola Sumber Daya Manusia yang ada di PT. Bank
Tabungan Negara (persero) dianggap belum mampumemenuhi kewajiban perusahaan kepada karyawan.Khususnya karyawan yang berposisi pada jabatan menengah kebawah. Hal ini terlihat berdasarkan gaji yang diperoleh setiap karyawan PT. Bank Tabungan Negara (persero) Tbk. Namun pada kenyataannya karyawan tidak memperoleh hal tersebut, sementara tuntutan perusahaan terhadap produktivitas karyawan sangat tingggi untuk mencapai tujuan perusahaan.memenuhi kewajiban perusahaan kepada karyawan. Khususnya karyawan yang berposisi pada jabatan menengah kebawah. Hal ini terlihat berdasarkan gaji yang diperoleh setiap karyawan PT. Bank Tabungan Negara (persero) Tbk. Namun pada kenyataannya karyawan tidak memperoleh hal tersebut, sementara tuntutan perusahaan terhadap produktivitas karyawan 
sangat tingggi untuk mencapai tujuan perusahaan.

\section{KAJIAN PUSTAKA Produktivitas}

Menurut Sinungan (2005: 17) produktivitas adalah sebagai hubungan antara hasil nyata maupun fisik ( barang - barang / jasa ) dengan masuknya yang sebenarnya. Misalnya saja " produktivitas adalah ukuran efisiensi produksi, suatu perbandingan antara hasil keluaran dan masuk atau (output) dan (input). Masukan sering dibatasi dengan masukan tenaga kerja, sedangkan keluaran diukur dalam kesatuan fisik bentuk dan nilai.

Menurut Komarudin (1992) di dalam Agustini (2011), produktivitas pada hakektnya meliputi sikap yang senantisa mempunyai pandangan bahwa metode kerja hari ini harus lebih baik dari metode kerja kemarin dan hasil yang dapat diraih.

\section{Gaji}

Gaji adalah "jasa yang dibayar secara periodik kepada pegawai yang tetap serta mempunyai jaminan yang pasti" (Hasibuan 1999: 133) didalam P.Siagian.Gaji adalah "imbalan yang diberikan oleh pemberi kerja kepada pegawai, yang penerimaannya bersifat rutin dan tetap setiap bulan" (Gito Sudarmo 1995: 299) didalam P.siagian.

\section{Pengertian Karir}

Handoko didalam Badriyah (2015), "karir adalah semua pekerjaan yang ditangani atau dipegang selama kehidupan kerja seseorang".Dengan demikian, karir menunjukkan perkembangan para pegawai secara individual dalam jenjang jabatan atau kepangkatan yang dapat dicapai selama masa kerja disuatu perusahaan. Simamora (2001: 504), berpendapat bahwa kata "karir" dapat dipandang dari beberapa perspektif yang berbeda, antara lain dari perspektif yang objektif dan subjektif. Dipandang dari perspektif yang subjektif, karier merupakan urutan posisi yang diduduki oleh seseorang selama hidupnya, sedangkan dari perspektif yang objektif, karir merupakan perubahan nilai, sikap, dan motivasi yang terjadi karena seseorang menjadi semakin tua.

\section{Lingkungan Kerja}

"Lingkungan kerja adalah serangkaian sifat kondisi kerja yang dapat diukur berdasarkan persepsi bersama dari para anggota organisasi yang hidup dan bekerjasama dalam suatu organisasi”, (Anbri 2010:4).

Sadarmayanti

mengatakan bahwa "lingkungan kerja adalah keseluruhan alat perkakas dan bahan yang dihadapi, lingkungan disekitarnya dimana seseorang bekerja, metode kerjanya, serta pengaturan kerja yang baik."

\section{METODE PENELITIAN}

Lokasi penelitian dilaksanakan pada Kantor PT Bank Tabungan Negara (Persero) Tbk KC Medan Jl.Pemuda Medan. Dalam penelitian ini sampel yang digunakan adalah karyawan Kantor PT Bank Tabungan Negara (Persero) Tbk KC Medan J1.Pemuda.Metode penelitian sampel menggunakan metode Purposive Sampling.variabel dalam penelitian ini adalah: a. Variabel bebas (Independen) :- Gaji (X1), Pengembangan Karir (X2), dan Lingkungan Kerja (X3). b. Variabel terikat (Dependen) : - Produktivitas Kerja ( Y ). 


\section{HASIL PENELITIAN DAN PEMBAHASAN \\ Hasil Penelitian}

Model analisis yang digunakan dalam penelitian ini adalah regresi berganda.Analisis regresi berganda dilakukan untuk mengetahui seberapa besar pengaruh variabel independen (Gaji, pengembangan karir dan Lingkungan kerja Fisik) terhadap variabel dependen (Produktivitas kerja karyawan) pada PT. Bank Tabungan Negara (Persero) Tbk Medan. Analisis ini dibantu dengan program pengolahan data Statistical Packages for Social Science 22,0 (SPSS). Koefisien regresi $\mathrm{X} 1$ sebesar 0,036 menunjukkan bahwa jika terjadi peningkatan satu satuan gaji maka produktivitas kerja karyawan akan meningkat sebesar 0,036 dengan asumsi variabel lain konstan. Koefisien regresi X2 sebesar 0,396 menunjukkan bahwa jika pengembangan karir ditingkatkan sebanyak satu satuan, maka produktivitas kerja karyawan akan meningkat sebesar 0,396 dengan asumsi variabel lain konstan. Koefisien regresi X3 sebesar 0,315 menunjukkan bahwa jika lingkungan kerja fisik ditingkatkan sebanyak satu satuan, maka produktivitas kerja karyawan akan meningkat sebesar 0,315 dengan asumsi variabel lain konstan.

Pengujian hipotesis penelitian dilakukan untuk menguji keempat hipotesis penelitian yang telah dipaparkan sebelumnya.Untuk mengetahui apakah variabel independen dalam model regresi berpengaruh terhadap variabel dependen, maka dilakukan pengujian dengan menggunakan uji $\mathrm{t}(\mathrm{t}$ test) dan uji $\mathrm{F}$ (F test).

Dari pengujia $t$ tabel di dapatkan: 1 . Variabel gaji memiliki thitung > ttabel, yaitu berpengaruh positif dan signifikan secara parsial terhadap priduktivitas kerja karyawan. 2. Variabel pengembangan karir thitung $>$ ttabel, yaitu sebesar $1.954>1.676$ dan taraf signifikansi sebesar $0.000<$ 0.05 sehingga dapat disimpulkan bahwa variabel pengembangan sebesar $2.687>1.676$ dan taraf signifikansi sebesar $0.003<0.05$ sehingga dapat disimpulkan bahwa variabel gaji. 3. karir berpengaruh positif dan signifikan secara parsial terhadap produktivitas kerja karyawan. 4. Variabel lingkungan kerja fisik thitung $>$ ttabel, yaitu sebesar $2.511>1.676$ dan taraf signifikansi sebesar $0.001<0.05$ sehingga dapat disimpulkan bahwa variabel pengembangan karir berpengaruh positif dan signifikan secara parsial terhadap produktivitas kerja karyawan. Variabel pengembangan karir secara parsial berpengaruh secara positif dan signifikan terhadap, produktivitas kerja karyawan PT.Bank Tabungan Negara (Persero) Tbk KC. Medan I Jl. Pemuda, hal ini terlihat dari nilai signifikan Insentif 1,954> dari t tabel yaitu 1.676 dan nilai signifikan 0.000 $<0,05$. Variabel lingkungan kerja fisik secara parsial berpengaruh secara positif dan signifikan terhadap, produktivitas kerja karyawan PT.Bank Tabungan Negara (Persero) Tbk KC. Medan I Jl. Pemuda, hal ini terlihat dari nilai signifikan Insentif 2,511> dari t tabel yaitu 1.676 dan nilai signifikan $0.000<0,05$.

Dari hasil penelitian juga membuktikan Hipotesis diterima 
dengan adanya hasil secara simultan (uji $\mathrm{F}$ ) yaitu $\mathrm{F}$ hitung $=4,761>\mathrm{F}$ tabel ( 2,84), dengan demikian dapat ditarik kesimpulan koefisien arah regresi berganda pada taraf signifikan 0,05 yang artinya gaji, pengembangan karir dan lingkungan kerja fisik berpengaruh positif dan signifikan terhadap produktivitas kerja karyawan PT.Bank Tabungan Negara (Persero) Tbk KC. Medan I Jl. Pemuda.

\section{PENUTUP}

Berdasarkan hasil dan pemba-hasan penelitian, maka penulis membuat beberapa kesimpulan sebagai berikut :

1. Dari hasil penelitian pada PT. Bank Tabungan Negara (Persero) KC Medan I Jl. Pemuda bahwa variabel gaji berpengaruh secara positif dan signifikan terhadap produktivitas kerja karyawan, hal ini sesuai dengan teori Gito Sudarmo yang menyatakan gaji adalah imbalan yang diberikan oleh pemberi kerja kepada pegawai, yang penerimaannya bersifat rutin setiap bulan.

2. Pengembangan karir berpengaruh secara positif dan signifikan terhadap produktivitas kerja karyawan, hal ini sesuai dengan teori Badriyah 2015 yang menyatakan karir menunjukkan perkembangan para pegawai secara individual dalam jenjang jabatan atau kepangkatan yang dapat dicapai selama masa kerja disuatu perusahaan.

3. Lingkungan kerja fisik berpengaruh secara positif dan signifikan terhadap produktivitas kerja karyawan, hal ini sesuai dengan teori Sedarmayanti 2011 yang menyatakan keadaan lingkungan kerja yang kurang baik dapat menuntut tenaga dan waktu yang lebih banyak serta tidak mendukung diperolehnya rancangan sistem kerja yang efesien.

4. Berdasarkan perhitungan uji t (uji varsial) dari ketiga variabel independen yaitu gaji(X1), pengenbangan karir (X2) dan lingkungan kerja fisik (X3).Variabel gaji (X1) memiliki pengaruh yang lebih besar terhadap produktivitas kerja karyawan organisasi. Hal ini dapat dilihat dalam faktor-faktor yang mempengaruhi produtivitas kerja yang tersusun dengan baik tentu akan menimbulkan semangat kerja para karyawan untuk bekerja lebih baik. Apabila tingkat penghasilan memadai maka dapat menimbulkan konsentrasi kerja dan kemampuan yang dimiliki dapat dimanfaatkan untuk meningkatkan produktivitas kerja.

5. Dari hasil penelitian pada PT. Bank Tabungan Negara (Persero) Tbk KC Jl. Pemuda I Medan, variabel gaji, pengembangan karir, dan lingkungan kerja fisik secara bersama-sama mempengaruhi produktivitas kerja karyawan PT. Bank Tabungan Negara (Persero) Tbk KC Jl. Pemuda I Medan dan menyatakan bahwa hipotesis diterima.

\section{DAFTAR PUSTAKA}

A.A. Anwar Prabu Mangkunegara. 2007. Evaluasi Kinerja SDM. Bandung Refika Aditama. 
JURNAL PLANS

Penelitian Ilmu Manajemen \& Bisnis

ISSN: 1978-7057

Agustini, Fauzia. 2011. Manajemen Sumberdaya Manusia Lanjutan, Madenatera

Anbri, Alvi. 2010. Pengaruh gaya kepemimpinan dan Lingkungan Kerja Terhadap Kinerja Karyawan Pada PT. Baank Central Asia, Tbk KCP PuloBrayan Medan. Skripsi

(http://repository.usu.ac.id) Diakses 28 November 2013.

Azwar, Saifudin. 2009. Metode Penelitian. Pustaka Pelajar: Yogyakarta

Badriyah, Mila. 2015. Manajemen Sumberdaya Manusia, Bandung. Pustaka Setia

Erniati, Cut dan Teridah Sembiring. 2013. "Pengaruh Fasilitas dan Pengembangan Sumber Daya Manusia Terhadap Produktivitas Kerja Karyawan Studi Kasus PTPN II Kebun Simpali Medan". Diakses 15 oktober 2013

Handoko, 2010.Training and Development, Teknik penilaian Ber Berbasis Kompetensi.Jakarta :

PT. Gramedia

Lubis, Winni Nadya. 2012. "Pengaruh Motivasi Kerja Dan Lingkungan Kerja Terhadap Kinerja Karyawan Pada Pusat Penelitian Kelapa Sawit (PPKS)". Skripsi. (http://repository.usu.ac.id) Diakses 2 Desember 2013.

Nitisemito, Alex. 2011. "Manajemen Personalia (Manajemen Sumber Daya Manusia). Cetakan Keempat
belas.Jakarta : Ghalia Indonesia.

Numruloh Muhammad, 2012 "Pengaruh Lingkungan Kerja Terhadap Produktivitas Kerja Dinas Pekerjaan Umum Provinsi Kalimantan Timur". Skripsi Fakultas Ekonomi, Manajemen Universitas 17 Agustus 1945 Samarinda, Samarinda. Indonesia.

P.Siagian Sondang. 2013. Manajemen Sumber Daya Manusia. Cetakan ke duapuluh satu.Jakarta : PT Bumi Aksara.

Riduwan \& Akdon. 2007. Rumus dan Data dalam Analisis Statistik untuk Penelitian (Administrasi PendidikanBisnis-Pemerintahan-SosialKebijakan-Ekonomi-HukumManajemen-Kesehatan). Alfabeta: Bandung.

Sedarmayanti. 2011. Tata Kerja dan Produktivitas Kerja : Suatu Tinjauan Dari Aspek Ergonomi atau Kaitan Antara Manusia dengan Lingkungan Kerjanya. Cetakan Ketiga. Bandung: Mandar Maju.

Sinungan 2005. 17. Sumber Daya Manusia Lanjutan, Tangerang, Alfabeta.

Sulaiman, Ardika. 2014. "Pengaruh Upah dan Pengalaman Kerja terhadap Produktivitas Karyawan Kerajinan Ukiran Kabupaten Subang". STIE Miftahul Huda Subang Volume 13, No. 1, Juni 2014, Hal.91-100.

$\begin{array}{rrr}\text { Utomo, } & 2014 . & \text { "Pengaruh } \\ \text { Pengembangan } & \text { Karir } \\ \text { Terhadap Kepuasan } & \text { Kerja }\end{array}$ 
JURNAL PLANS

Penelitian Ilmu Manajemen \& Bisnis

ISSN: 1978-7057

Karyawan dengan Motivasi Kerja Sebagai Variabel Intervening)"

Sugiyono.2008. Metode Kuantitatif dan Kualitatif $R \& D$. CV. Alfa Beta, Bandung. .2009. Metode Penelitian Kualitatif Bandung: Alfabeta. .2010. Metode Penelitian Kualitatif (Pendekatan Kuantitatif, Kualitatif, dan $R \& D)$ Bandung: Alfabeta.
2011. Metode Kuantitatif dan Kualitatif $R \& D$. CV. Bandung: Alfabeta.

Umar, Husein. 2008. Riset Strategi Pemasaran. PT. Gramedia Pustaka Utama: Jakarta

Utomo, 2014. "Pengaruh Pengembangan Karir Terhadap Kepuasan Kerja Karyawan dengan Motivasi Kerja Sebagai Variabel Intervening)" 